\title{
17. SITE 461: INNER WALL OF THE MARIANA TRENCH ${ }^{1}$
}

\author{
Shipboard Scientific Party²
}

\section{HOLE 461}

Date occupied: 10 May 1978

Date departed: 11 May 1978

Time on hole: 28 hours

Position: $17^{\circ} 46.05^{\prime} \mathrm{N}$; $147^{\circ} 41.18^{\prime} \mathrm{E}$

Water depth (sea level; corrected m, echo-sounding): 7034

Water depth (rig floor; corrected m, echo-sounding): 7044

Bottom felt (m, drill pipe): 7039

Penetration (m): 20.5

Number of holes: 1 of 2

Number of cores: 3

Total length of cored section $(\mathrm{m}): 20.5$

Total core recovered $(\mathrm{m}): 8.62$

Core recovery $(\%): 42$

Oldest sediment cored:

Depth sub-bottom (m): 20.5

Nature: mud and conglomerate

Age: Quaternary

\section{HOLE 461A}

Date occupied: 11 May 1978

Date departed: 11 May 1978

Time on hole: 20 hours, 30 minutes

Position: $17^{\circ} 46.02^{\prime} \mathrm{N} ; 147^{\circ} 41.26^{\prime} \mathrm{E}$

Water depth (sea level; corrected m, echo-sounding): 7034

Water depth (rig floor; corrected m, echo-sounding): 7044

Bottom felt (m, drill pipe): 7044

Penetration $(\mathrm{m}): 15.5$

Number of holes: 2 of 2

Number of cores: 2

Total length of cored section $(\mathrm{m}): 15.5$

Total core recovered $(\mathrm{m}): 7.26$

\footnotetext{
${ }_{2}^{1}$ Initial Reports of the Deep Sea Drilling Project, Volume 60.

2 Donald M. Hussong (Co-Chief Scientist), Hawaii Institute of Geophysics, Honolulu, Hawaii; Seiya Uyeda (Co-Chief Scientist), Earthquake Research Institute, University of Tokyo, Tokyo, Japan; René Blanchet, Université de Bretagne Occidentale, Brest, France; Ulrich Bleil, Institut für Geophysik, Ruhr Universität, Bochum, Federal Republic of Germany; C. Howard Eltis, Marathon Oil Company, Denver Research Center, Littleton, Colorado; Timothy J. G. Francis, Institute of Oceanographic Sciences, Surrey, United Kingdom; Patricia Fryer, Hawaii Institute of Geophysics, Honolulu, Hawaii; Ki-Iti Horai, LamontDoherty Geological Observatory, Palisades, New York; Stanley Kling, Marine Life Research Group, Scripps Institution of Oceanography, La Jolla, California (present address: 416 Shore View Lane, Leucadia, California); Arend Meijer, Department of Geosciences, University of Arizona, Tucson, Arizona; Kazuaki Nakamura, Earthquake Research Institute, University of Tokyo, Tokyo, Japan; James H. Natland, Deep Sea Drilling Project, Scripps Institution of Oceanography, La Jolla, California; Gordon H. Packham, Department of Geology and Geophysics, University of Sydney, Sydney, N.S.W. Australia; and Anatoly Sharaskin, Vernadsky Institute of Geochemistry, U.S.S.R. Academy of Sciences, Moscow, U.S.S.R.
}

\begin{abstract}
Core recovery $(\%): 47$
Oldest sediment cored:

Depth sub-bottom (m): 15.5

Nature: Conglomerate

Age: Quaternary, reworked Eocene-Oligocene

Principal results: (Holes 461 and 461A)-At Site 461, two holes were drilled with the SP-2B objectives of probing into the deep inner wall of the Mariana Trench. The site was located on a very small patch of sediment on a local high, which, we hoped, would be isolated from the coarse gravels and talus cobbles that caused drilling difficulty at Site 460 . Penetrations were, unfortunately, limited to 20.5 meters (core recovery rate $42 \%$ ) at Hole 461 and 15.5 meters (recovery rate $47 \%$ ) at Hole $461 \mathrm{~A}$, due to drilling difficulties resulting from inadequate sediment cover over igneous and metamorphic cobbles. Sediments recovered show an upper 1 to 3 meters of siliceous ooze underlain by several meters of zeolitic clay with vitric mud and siliceous mud of latest Quaternary age. Core 1 of Hole 461A contains mixed assemblages of late Oligocene and early Oligocene-late Eocene calcareous nannofossils. The lower approximately 10 meters comprises subangular and subrounded granular to pebbly conglomerates with igneous, metamorphic, and sedimentary fragments, having no age-diagnostic assemblages. Cobbles of metabasalts, metadiabases, and metagabbros of amphibolite facies were recovered. True in situ basement was not attained.
\end{abstract}

\section{BACKGROUND AND OBJECTIVES}

Site 461 represented a second attempt to meet the scientific objectives of target site SP-2B after the shallow penetration achieved at Site 460 . In Holes 460 and $460 \mathrm{~A}$ we recovered an exceptionally interesting set of cores with a wide variety of ages and lithologies, even though we had penetrations of only 85 and 99.5 meters. As the cores were first described, the initial shipboard interpretation was that they contained both an undisturbed Eocene-Oligocene section that had come down, perhaps as a slump block, from above the carbon compensation depth (CCD) high on the trench wall, as well as a lot of reworked material (as old as Cretaceous) that had apparently fallen downslope.

We were very disappointed that the sediment pond at Site 460 contained such a great amount of coarse sand, gravel, and cobbles-presumably from upslope-that the holes were unstable for drilling and permitted only shallow penetration. We did not feel that basement was reached in either hole, even though they both bottomed out in igneous rocks.

In the second attempt to meet the objectives of SP$2 \mathrm{~B}$, and to assist interpretation of the complex intervals recovered from Holes 460 and $460 \mathrm{~A}$, we decided to drill at a second location deep on the inner wall of the trench (Figs. 1 and 2).

Because adequate hole stability is required to get the basement penetration which is important to the overall objectives discussed in the fore-arc and trench back- 


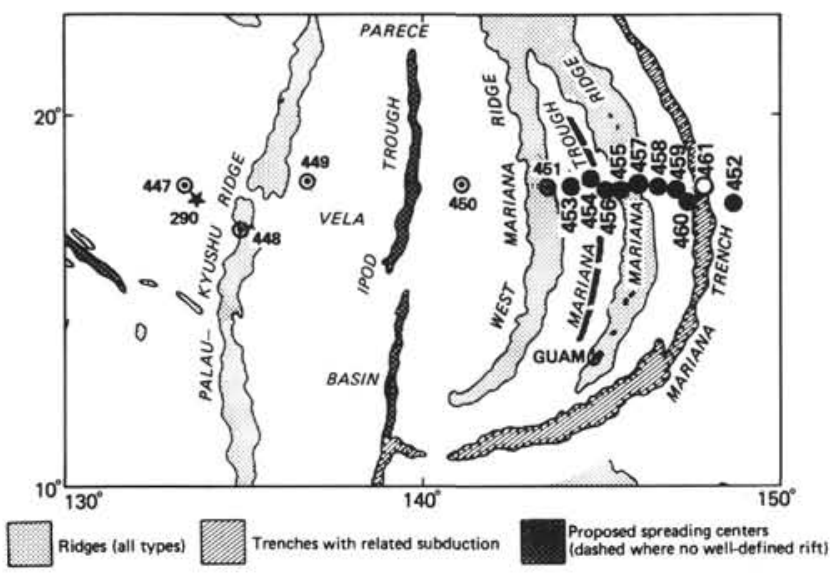

Figure 1. Location of Site $461(\mathrm{O})$ and the other sites $(\bullet)$ drilled on Leg 60.

ground and objectives chapter (Hussong and Uyeda, this volume), we decided to locate Site 461 on a local bathymetric high (Fig. 3). We hoped that such a high would be isolated from deposition of the coarser material coming down the trench wall.

The site was selected on the basis of site survey data that showed a re-entrant deep on the trench wall, where a local high (Fig. 2) was separated from the trench wall by a pond with a depth of over 7200 meters. The small bathymetric high rises to about 6975 meters. The entire re-entrant is anomalous, and could be a slump feature or some other product of vertical tectonic activity. We hoped, therefore, that material on the anomalous high might be indicative of transport from above (deposition above the $\mathrm{CCD}$ ), or below (Pacific plate material?) its present location.

\section{OPERATIONS}

After nearly nine hours of transit and surveying, a very small patch of sediment (Fig. 4) was located on the slight bathymetric high just described. Although less than 20 meters of sediment could be observed on the $3.5-\mathrm{kHz}$ record at this site, it was the only sediment encountered during the entire survey period. With some feelings of desperation, a $16-\mathrm{kHz}$, single-life beacon was dropped on the sediments, in 7034 meters (corrected PDR) of water, at 2100 on 9 May 1978.

This is the deepest site that has ever been drilled in the oceans. The 7059.5 meters of drill string used for both Holes 461 and $461 \mathrm{~A}$ is also the longest drill string every deployed by the Glomar Challenger.

A standard 120-meter bottom-hole assembly and F93CK bit was rigged, and the ship was offset from the beacon $420^{\prime} \mathrm{S}$ and $280^{\prime} \mathrm{E}$ to a position of $17^{\circ} 46.05^{\prime} \mathrm{N}$, $147^{\circ} 41.18^{\prime} \mathrm{E}$.

The bit was spud in at a depth of 7039 meters $(7029 \mathrm{~m}$ below sea level), at 1637 local time on 10 May. The coring summary and drilling rate are given in Table 1 and Figure 5A, respectively. Unfortunately, the sediment thickness was no greater than indicated on the $3.5-\mathrm{kHz}$ record, so by Core 3 we were into apparent basement (actually this material was probably a rubble layer of ig-

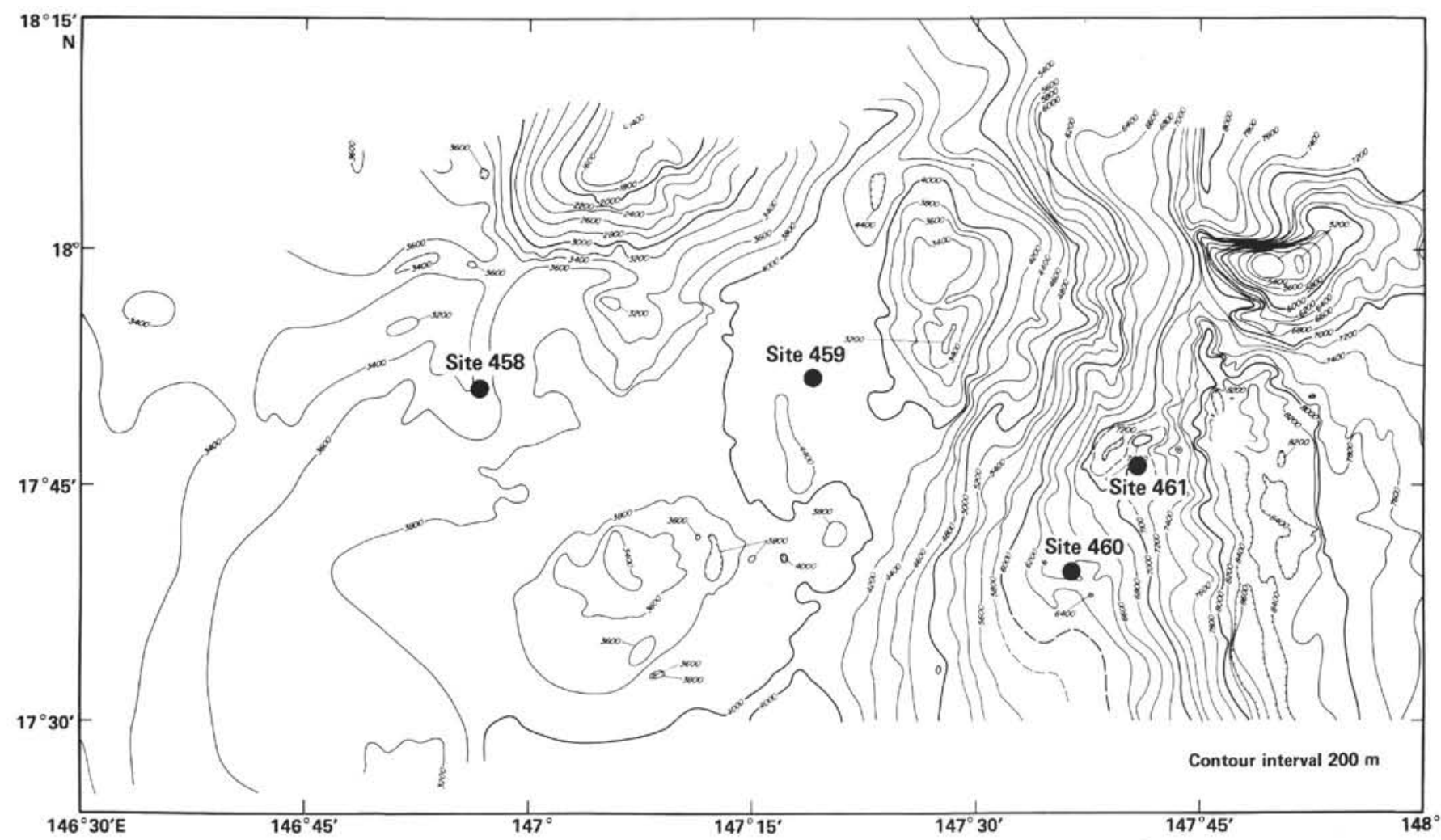

Figure 2. Bathymetry of the region around Site 461 . Contours in intervals of 200 meters (corrected). 


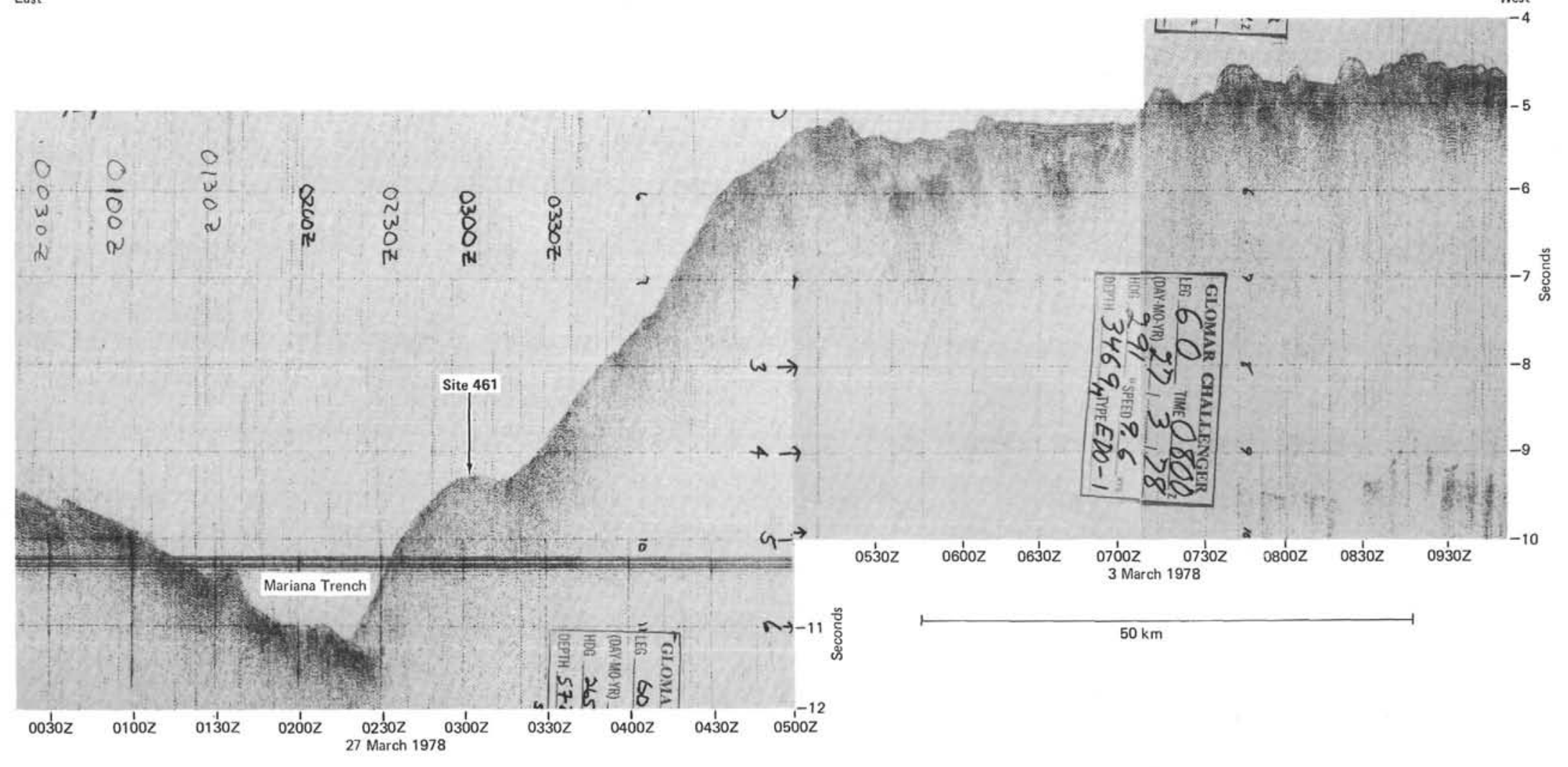

Figure 3. Glomar Challenger air-gun profile showing arc-side trench wall and bench in which Site 461 was drilled. 


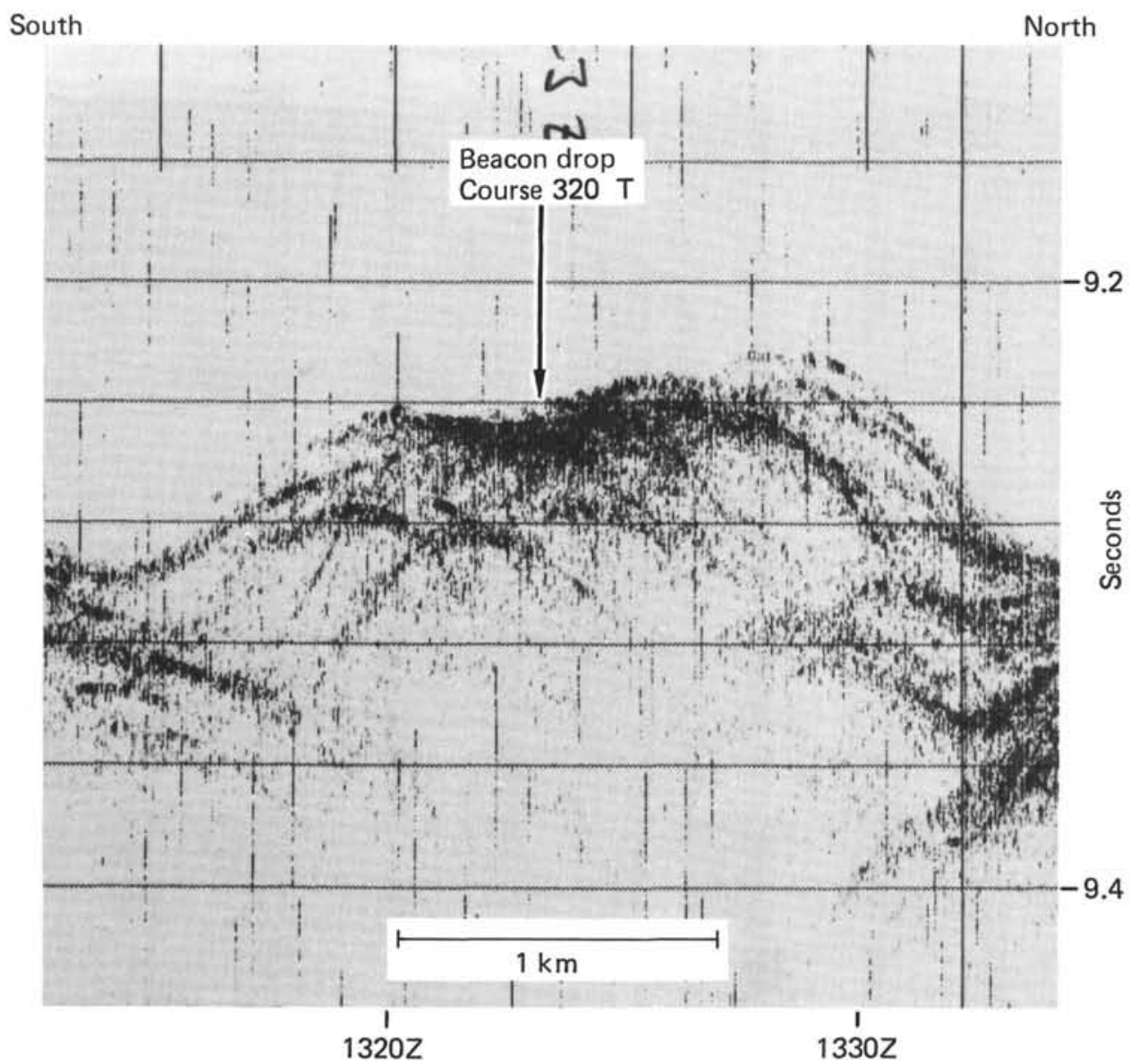

Figure 4. Glomar Challenger 3.5-kHz record over Site 461 showing small perched sediment pond in which the site was drilled.

Table 1. Coring summary, Site 461.

\begin{tabular}{|c|c|c|c|c|c|c|c|}
\hline Core & $\begin{array}{l}\text { Date } \\
\text { (May } \\
\text { 1978) }\end{array}$ & Time & $\begin{array}{l}\text { Depth from } \\
\text { Drill Floor } \\
\text { (m) }\end{array}$ & $\begin{array}{l}\text { Depth below } \\
\text { Sea Floor } \\
\text { (m) }\end{array}$ & $\begin{array}{l}\text { Length } \\
\text { Cored } \\
\text { (m) }\end{array}$ & $\begin{array}{l}\text { Length } \\
\text { Recovered } \\
\text { (m) }\end{array}$ & $\begin{array}{c}\text { Recovery } \\
(\%)\end{array}$ \\
\hline \multicolumn{8}{|l|}{ Hole 461} \\
\hline 1 & 10 & 1836 & $7039.0-7040.5$ & $0-1.5$ & 1.5 & 0.72 & 48.0 \\
\hline 2 & 10 & 2054 & $7040.5-7050.0$ & $1.5-11.0$ & 9.5 & 6.35 & 66.8 \\
\hline \multirow[t]{2}{*}{3} & 11 & 0036 & $7050.0-7059.5$ & $11.0-20.5$ & 9.5 & 1.55 & 16.3 \\
\hline & & & & & 20.5 & 8.62 & 42.0 \\
\hline \multicolumn{8}{|c|}{ Hole $461 \mathrm{~A}$} \\
\hline & 11 & 0442 & $7044.0-7050.0$ & $0-6.0$ & 6.0 & 5.97 & 99.5 \\
\hline 2 & 1 & 0735 & $7050.0-7059.5$ & $6.0-15.5$ & 9.5 & 1.29 & 13.5 \\
\hline Total & & & & & 15.5 & 7.26 & 46.8 \\
\hline
\end{tabular}

neous rocks). It required 65 minutes of rotation to penetrate 9.5 meters. As the bottom-hole assembly was still almost completely unsupported, and we were very close to all maximum specifications for load limitation because of the water depth, we were forced to abandon the hole when penetration was so slow.

The bottom-hole assembly was then raised above the mudline and the ship shifted to $800^{\prime}$ South and $600^{\prime}$ East of the beacon (to $17^{\circ} 46.02^{\prime} \mathrm{N}, 147^{\circ} 41.26^{\prime} \mathrm{E}$ ) to try a second hole in the same sediment pond. Hole $461 \mathrm{~A}$ was spud in at 0313 local time on 11 May, in 7044 meters (7034 $\mathrm{m}$ water depth). The coring summary and drilling rate of this hole are given in Table 1 and Figure 5B. Our luck had run out, however, because the sediments were
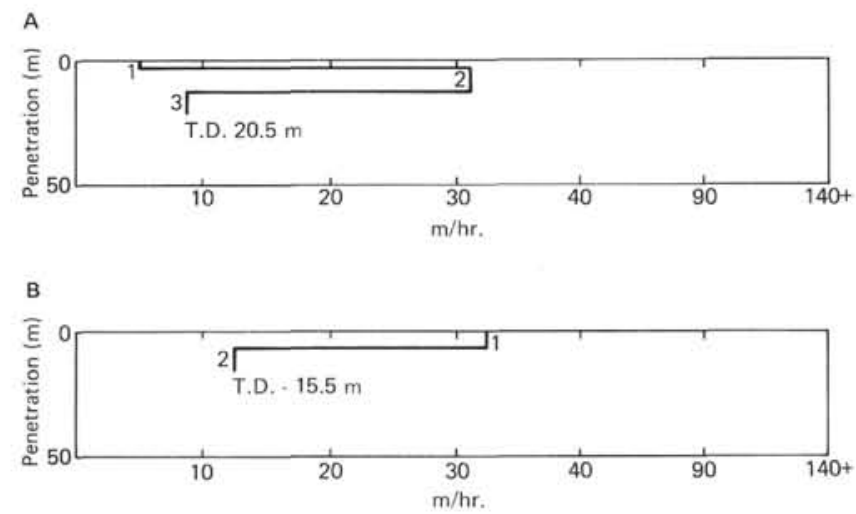

Figure 5. Drilling rate for (A) Hole 461 and (B) Hole 461A. T.D. is total depth sub-bottom. Cores are indicated on the figure.

still too thin. After having to rotate for 46 minutes to cut Core 2, this hole was also abandoned for obvious drill string safety reasons.

The bit cleared the mudline at 0836 local time, and the entire string was on deck and secured at 2136 on 11 May.

The Challenger departed Site 461 at 2200 local time on 11 May, and began a survey pattern of the inner wall 
of the trench in the hope of finding a sediment pond that may have been missed during site surveys, but which could be drilled as a third effort to meet the objectives of target site SP-2B.

No sediments were located by 1500 on 12 May. In the face of inadequate time to conduct further useful drilling, but with some ship time still available, we proceeded east to the Pacific plate to acquire a geophysical profile needed for regional interpretation of Site 452 (SP-1B). After acquiring these final data, the Challenger proceeded to Guam, arriving on the afternoon of May 15.

\section{LITHOLOGY}

Holes 461 and $461 \mathrm{~A}$ were drilled about 160 meters apart. Data for Hole 461A are given in parentheses. A total of 20.5 meters $(15.5 \mathrm{~m})$ of sediments was penetrated from 7029 to 7049.5 meters (7034 to $7049.5 \mathrm{~m}$ ), of which 8.62 meters, 42 percent $(7.26 \mathrm{~m}, 47 \%)$ was recovered.

Three lithologic units are recognized and are common to both holes. The three units, or at least the upper two, are probably no older than Pleistocene. The pebbly mud, lithologically similar to Unit II, also appears in Unit III (Fig. 6).

Unit I: 1.5 meters $(2.5 \mathrm{~m}), 0.0-1.5 \mathrm{~m}(0-2.5 \mathrm{~m})$; Core 1 (Core 1, Sections 1 through 2, $100 \mathrm{~cm}$ ).

Moderate yellowish brown siliceous ooze (dark yellowish brown and greenish gray siliceous ooze) with a few thin layers of olive-gray to black crystal vitric mud in the two holes.
In the siliceous ooze, diatoms are abundant up to 60 percent $(30 \%)$, and volcanic ash content is also high, up to 15 percent $(20 \%)$. The ashes are more than half crystals (feldspars and heavy minerals). Alteration of the glass to palagonite is common. In Hole 461, a sandstone pebble partially encrusted by manganese occurs as well as several larger fragments, including a metagabbro pebble.

Unit II: 9.5 meters $(3.5 \mathrm{~m}), 1.5-11.0$ meters $(2.5-6.0$ m); Core 2 (Core 1, Section 2, $100 \mathrm{~cm}$ to $1, \mathrm{CC}$ ). Zeolitic clay, vitric mud, and siliceous mud with a few thin ash(?) layers (crystal vitric mud with common igneous pebbles).

In Hole 461, a small amount of zeolite $(5 \%)$ in zeolitic clay occurs in the upper half, while siliceous ooze similar to that in Unit I occurs in the lower half. Disturbance is much higher in Hole 461A. Whether the disturbance represents original sedimentary texture or is merely the result of drilling is not clear. Drilling disturbance may be more plausible, because this unit in Hole $461 \mathrm{~A}$ contains more hard igneous rock pebbles than the overlying Unit I, which shows only moderate drilling disturbance. Two isolated pieces of calcareous ooze are also contained in Hole 461A.

Unit III: 9.5 meters $(9.5 \mathrm{~m}), 11.0-20.5$ meters $(6.0-15.5 \mathrm{~m})$; Core 3 (Core 2). Unconsolidated subangular to subrounded granule and pebble conglomerates.

The conglomerate consists of both igneous and sedimentary rocks. The dominant rocks are igneous and metamorphic in Hole 461A, and dusky yellow or

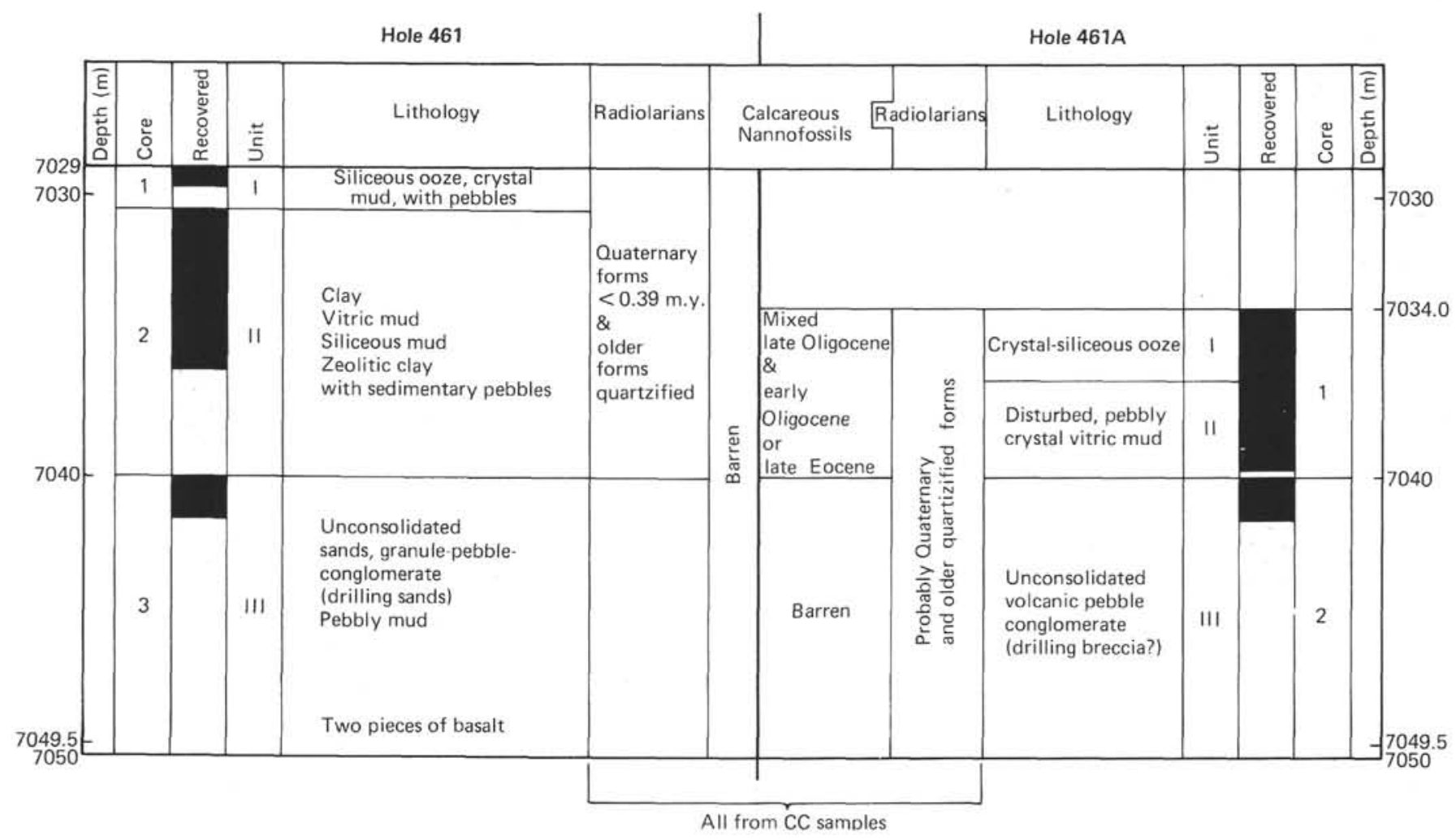

Figure 6. Lithologic summary, Holes 461 and $461 \mathrm{~A}$. 
slightly browner sedimentary rocks in Hole 461 , where igneous and metamorphic rocks are smaller (except for a few pebbles). Very coarse sand is abundant.

In Hole 461, Core 3, Section 1 between intervals 65 and $125 \mathrm{~cm}$, pebbly mud similar to Unit II is observed.

Paleontological age control is poor for sediments at this site (see Biostratigraphy), so sediment accumulation rate calculations were not made.

\section{BIOSTRATIGRAPHY}

\section{Summary}

The upper part of the section cored in Holes 461 and 461A can be dated as Quaternary on the basis of radiolarians. Cores 1 and 2 in both holes are both within the two latest Quaternary zones, which are no older than $0.37 \mathrm{~m} . \mathrm{y}$. Core 3 of Hole 461 contains no agediagnostic forms.

Core 1 of Hole $461 \mathrm{~A}$ contains a mixed assemblage of late Oligocene, early Oligocene-late Eocene, and Late Cretaceous calcareous nannofossils.

Reworked Cretaceous radiolarians in both holes are preserved as both opaline and crystalline silica, indicating different ages. However, many species are undescribed, precluding precise age assignments.

No foraminifers were observed in samples from this site.

\section{Nannofossils}

All of the samples from Hole 461 and $461 \mathrm{~A}$ are barren, except Samples 461A-1-3, 90-91 cm; 461A-1-4, $90-91 \mathrm{~cm}$; and $461 \mathrm{~A}-1, \mathrm{CC}$, which contain mixed late Oligocene, early Oligocene or late Eocene, and Late Cretaceous assemblages.

A sample of the muddy water found in association with Sample 461A-2-1, Bottom, was also found to contain a few specimens of Oligocene or late Eocene nannofossils.

\section{Radiolarians}

In both Holes 461 and $461 \mathrm{~A}$, Cores 1 and 2 contain Quaternary radiolarians, with the latest Quaternary Buccinosphaera invaginata Zone recognizable in the upper part of Core 1. No other zones can be diagnosed in these cores. No age-diagnostic radiolarians were recovered from Core 3 .

Cretaceous assemblages are admixed through both holes. Some are well preserved (opal) and others quartzified, indicating derivation from more than one source horizon. No zone-diagnostic forms can be recognized.

\section{ACCUMULATION RATES}

Because of the disturbed and slumped nature of the sediments we cored, and poor biostratigraphic control, no accumulation rates were calculated for Site 461 .

\section{GEOCHEMISTRY}

One sample was taken for pore water chemistry at Site 461. The data are given in Gieskes and Johnson (this volume).
Pore fluids in this near mudline sample $(3 \mathrm{~m}$ below the sea floor) have lower salinity, chlorinity, and magnesium than surface sea water at the site. They also have higher calcium. Since the sediments were so close to the sediment surface at the time they were sampled, these compositional differences probably reflect the composition of sea water at a depth of nearly 7000 meters in the Mariana Trench.

\section{STRATIGRAPHIC SYNTHESIS}

The nature of the sediments cored in the two holes at Site 461, their stratigraphic relationships and fossil assemblages, and the topographic relief near the site, are all strongly indicative of a Quaternary-slump or olistostrome origin for the section.

The three stratigraphic units in the two holes occur grossly in a sequential manner, but sometimes appear to interfinger with each other. Thus in Hole 461, siliceous ooze (similar to Unit I) occurs in the lower half of Unit II, and pebbly mud (similar to Unit II) occurs in the lower half of Unit III. This repetition of sedimentary units combined with the occurrence of pebbly mud suggest that the sedimentary sequence resulted from submarine slumping or sliding. Topography surrounding the site favors this interpretation. The hill where Site 461 is located seems to be a slump block from the upper trench slope where contours between 7000 and 5600 meters appear to invade the slope (Fig. 2).

This interpretation is also supported by fossil assemblages of radiolarians and calcareous nannofossils which indicate redeposition of older sediments. Both Units I and II in Hole 461 and Units II and III in Hole 461A contain Quaternary as well as substantially older (Mesozoic?) quartzified forms of radiolarians. Hole 461 is barren of nannofossils, but Unit II in Hole 461 contains poorly preserved, mixed late Oligocene and early Oligocene or late Eocene assemblages (this also indicates that the depth of this site was below the CCD at that time).

Thus, in the source area for the probable Quaternary slump or slide deposits at this site, there may be exposed sedimentary rocks of various Cenozoic ages as well as igneous and metamorphic rocks. The occurrence of a manganese-encrusted pebble in Unit I in Hole 461 is consistent with this inference. The occurrence of patches of calcareous ooze in Unit II in Hole 461A suggests that at least part of the source area was above the CCD, and that the deposition was so rapid that the calcareous ooze was quickly buried.

\section{IGNEOUS AND METAMORPHIC ROCKS}

At Site 461 igneous and metamorphic rocks were recovered, intermixed with sediments or as loose fragments of drilling breccia. Both the sediment lithology (see Lithology section) and the wide compositional range of the rock fragments indicate that the sequence cored at this site was emplaced by mass movement. The rock fragments range in size from gravel to cobbles with maximum diameters of $7 \mathrm{~cm}$. Sixteen pieces from dif- 
ferent levels of the cored sequence were studied in thin sections.

\section{Petrography}

Half of the sectioned rocks are metabasalts and metadiabases. The most altered varieties contain amphibole $(20-50 \%)$, quartz $(7-20 \%)$, plagioclase $(30-50 \%)$, magnetite $(5-8 \%)$, accessory epidote, and sphene. Partly recrystallized plagioclase (andesine?), together with quartz, forms the granoblastic matrix of these rocks. The partly recrystallized plagioclases enclose the original plagioclase laths and acicular crystals of secondary amphibole which are associated with magnetite and sphene. Quartz also fills vesicles and narrow veins. True poikiloblasts of plagioclase, enclosing amphibole, magnetite, and quartz grains, were observed in thin section 461A-2-1, 34-35 $\mathrm{cm}$, indicating near-equilibrium recrystallization under amphibolite facies conditions. However, even in this rock no real foliation or other kind of strain texture can be observed. All of the primary rock textures remain unchanged.

The less metamorphosed of these rocks contain abundant clay minerals instead of amphibole; some chlorite, epidote, zeolite, and often quartz. Pyroxene relicts are as rare here as in the highly altered rocks.

Gabbroic cobbles are less abundant $(25 \%)$ and more variable in texture and composition. The freshest rock of this group (Sample 461A-1-2, 118-120 cm) is a twopyroxene gabbro with granular texture containing plagioclase (ca. $\left.\mathrm{An}_{60} ; 40 \%\right)$, augite $(40 \%)$, and orthopyroxene $(20 \%)$; both pyroxenes have exsolution lamellae. Several fractures in this rock are filled with clay minerals, but otherwise secondary minerals are absent. Other gabbroic clasts, presumably of the same original composition, are more intensively altered and usually contain secondary quartz and amphibole accompanied by a low-grade assemblage of chlorite, epidote, sericite, sphene, and zeolite. Some of them have cumulus textures where both pyroxenes were intercumulus minerals before alteration. In the highly altered Sample 461-1-1, $78-80 \mathrm{~cm}$, poikiloblasts of amphibole enclose the plagioclase and magnetite grains.

One of the gabbro pieces contains brecciated material adhered to one side of the fragment, and some others have tectonized surfaces indicating a possible origin from brecciated source materials. This is evidenced by the presence of a true polymict breccia fragment (Sample 461A-1-3, 74-75 cm) containing two separate pieces of gabbros and basalt cemented by zeolite matrix with angular, sometimes very fine grained gabbroic clasts.

The other studied rock types are:

1) a small piece of epidosite;

2) altered (clay only) sparsely phyric, vesicular augite-plagioclase basalt; and

3) a fresh piece of almost completely hyaline sideromelane with rare microliths of plagioclase.

\section{Discussion}

The mode of occurrence and the diversity of rocks recovered at Holes 461 and 461A suggest that basement was not reached. In general, the igneous and metamorphic rock assemblage recovered in these two holes is quite similar to that recovered at Site 460 . Further, certain aspects of these igneous rocks at both Sites 460 and 461 resemble the polymict breccia of Site 453 . As at Site 453 in the western Mariana Trough, the dominant rock types on the inner trench wall are basalts and gabbros that had been subjected to rather high-grade metamorphism before brecciation and to retrograde metamorphism after brecciation. However, there are also some distinct differences between these two rock assemblages.

The rocks of Sites 460 and 461 seem to be metamorphosed under originally lower grade conditions. The biotite (or stilpnomelane) abundant in Site 453 rocks is totally absent here. No high-pressure, low-temperature metamorphic minerals were found in the Site 460 and 461 rocks and no real tectonic fabrics were observed. In addition, quartz is a common mineral phase in these rocks, whereas it was encountered only as a rare, cementforming mineral in the breccias at the western Mariana Trough site.

It is apparent that the geological and tectonic history of brecciated metabasite assemblages now exposed in frontal areas of the Mariana arc and the West Mariana Ridge have some important similarities, but are different in many important details.

\section{PHYSICAL PROPERTIES}

Compressional wave velocity, wet-bulk density, saltcorrected water content, porosity, and acoustic impedance were determined for cores recovered from Holes 461 and 461A. Much of the material recovered from both holes was of a gravelly or conglomerate nature, and therefore unsuitable for velocity or density measurements. The few velocity-density parameters that have been determined are given in Table 2. Thermal conductivities are reported in Horai (this volume).

\section{SUMMARY AND CONCLUSIONS}

The two holes drilled at Site 461 represent a second attempt to achieve the objectives of target SP-2B: to determine the origin (oceanic or island arc) of the material composing the inner wall of the Mariana Trench and to decipher the history of formation of the outer fore-arc.

Only 20.5 meters and 15.5 meters were penetrated at Holes 461 and 461 A, respectively, before a rubble layer of igneous rocks made further drilling impossible. Igneous and metamorphic cobbles recovered from the bottom of these holes are mostly metabasalts, metadiabases, and (less abundantly) metagabbros, of up to amphibolite facies. On the whole, the rocks are similar 
Table 2. Physical properties measurements, Site 461 .

\begin{tabular}{|c|c|c|c|c|c|c|c|c|}
\hline $\begin{array}{c}\text { Sample } \\
\text { (interval in } \mathrm{cm} \text { ) }\end{array}$ & $\begin{array}{l}\text { Depth } \\
\text { (m) }\end{array}$ & $\begin{array}{c}\text { Sound } \\
\text { Velocity } \\
\text { (vertical) } \\
(\mathrm{km} / \mathrm{s})\end{array}$ & $\begin{array}{l}\text { GRAPE } \\
\text { 2-minute } \\
\text { Wet-Bulk } \\
\text { Density } \\
\left(\mathrm{g} / \mathrm{cm}^{3}\right)\end{array}$ & $\begin{array}{c}\text { Water } \\
\text { Content } \\
\text { (salt- } \\
\text { corrected) } \\
(\%)\end{array}$ & $\begin{array}{c}\text { Porosity } \\
(\%)\end{array}$ & $\begin{array}{l}\text { Wet-Bulk }{ }^{b} \\
\text { Density } \\
\left(\mathrm{g} / \mathrm{cm}^{3}\right)\end{array}$ & $\begin{array}{c}\text { Acoustic } \\
\text { Impedance } \\
\left(\mathrm{g} / \mathrm{cm}^{2} \mathrm{~s} \times 10^{5}\right)\end{array}$ & Rock Type \\
\hline \multicolumn{9}{|l|}{ Hole 460} \\
\hline $2-1,100-102$ & 2.50 & 1.55 & 1.48 & 55.9 & 77.3 & 1.42 & 2.20 & Stiff clay \\
\hline $2-2,110-112$ & 4.10 & 1.57 & 1.47 & 55.5 & 77.4 & 1.43 & 2.25 & Stiff clay \\
\hline $2-3,68-70$ & 5.18 & 1.52 & & 68.5 & 85.3 & 1.27 & 1.93 & Soft mud \\
\hline Hole 461A & 0.86 & 152 & & 570 & 78.6 & 4.41 & 2.14 & Soft mud \\
\hline
\end{tabular}

to those at Site 460 . From the diversity of the rock types among the cobbles, we consider that true basement was not reached at either Site 460 or 461 .

The sediments above the igneous rubble in both holes at Site 461 comprise an olistostrome with mostly later Oligocene and early Oligocene-late Eocene calcareous nannofossils and poorly preserved Cretaceous radiolarians reworked into latest Quaternary sediments.
Site 461 is located on a bathymetric high that is apparently part of a large slump which extends down into the trench axis (Hussong and Fryer, this volume). It is not surprising, therefore, that we recovered sediments that apparently came from a sequence with ages and lithology similar to those of Site 460 and that were apparently involved in a slump down the trench wall in the latest Quaternary. 


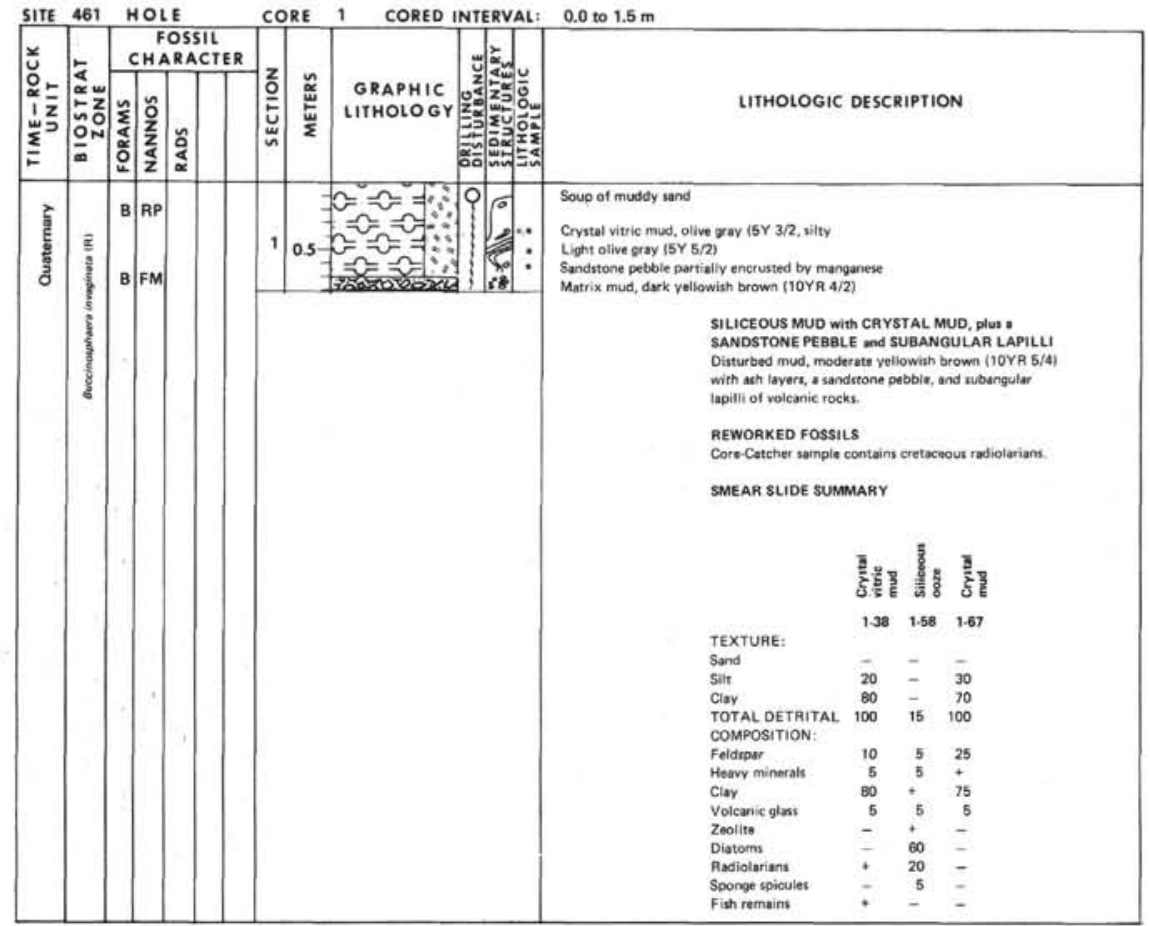

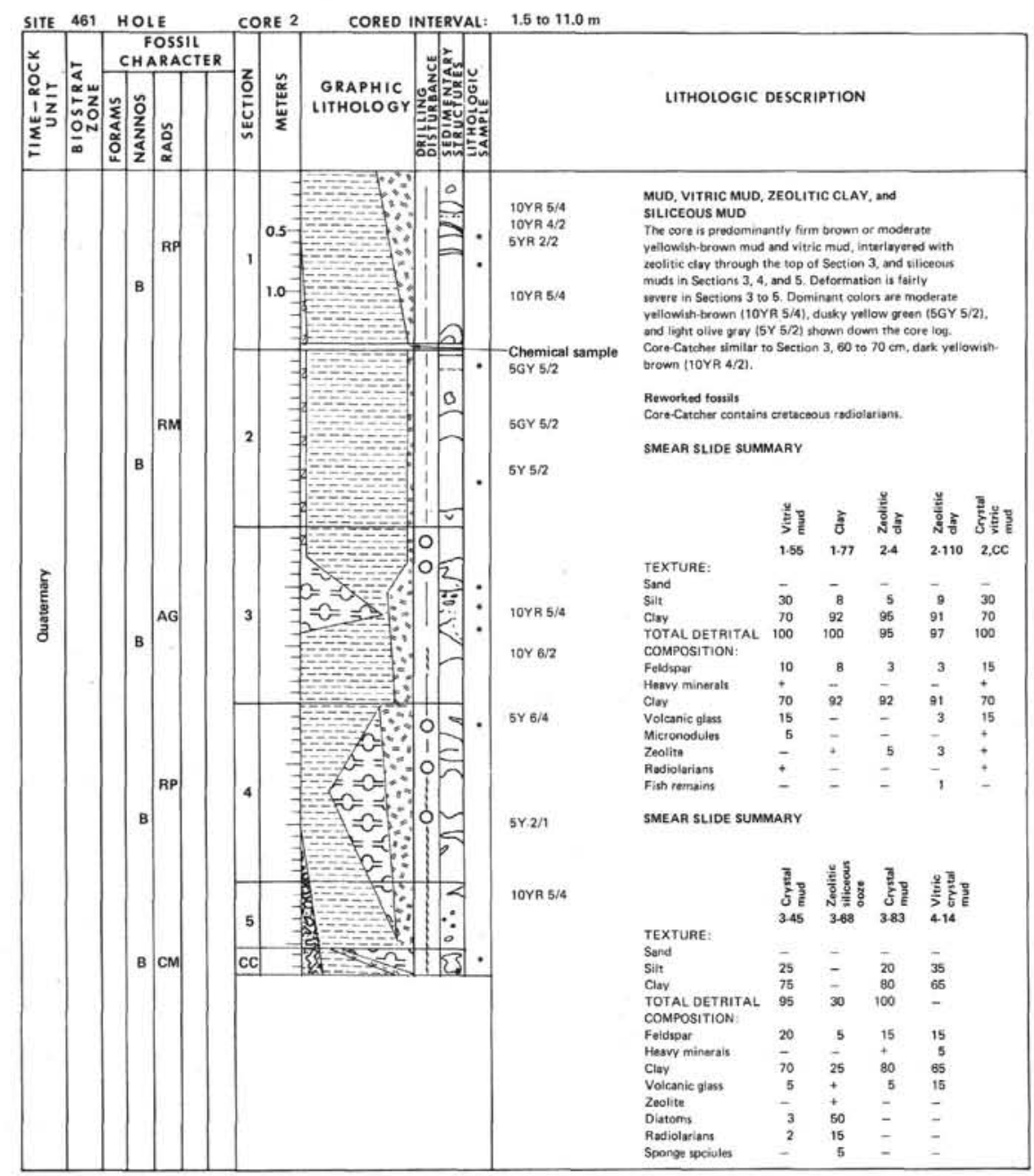




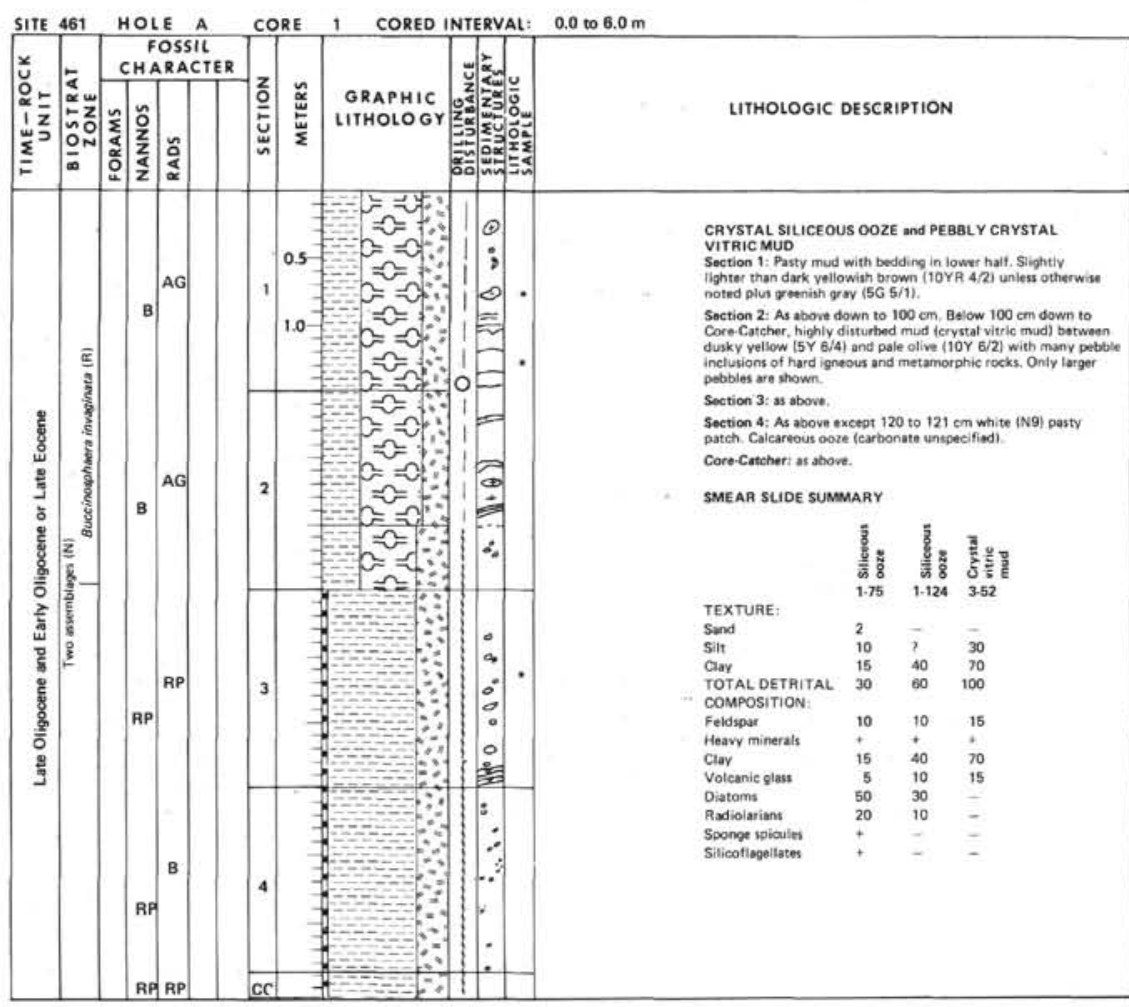

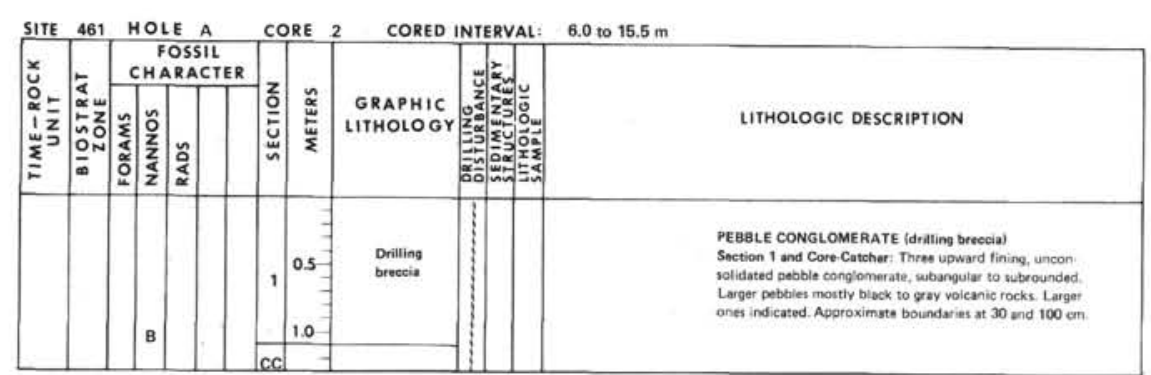




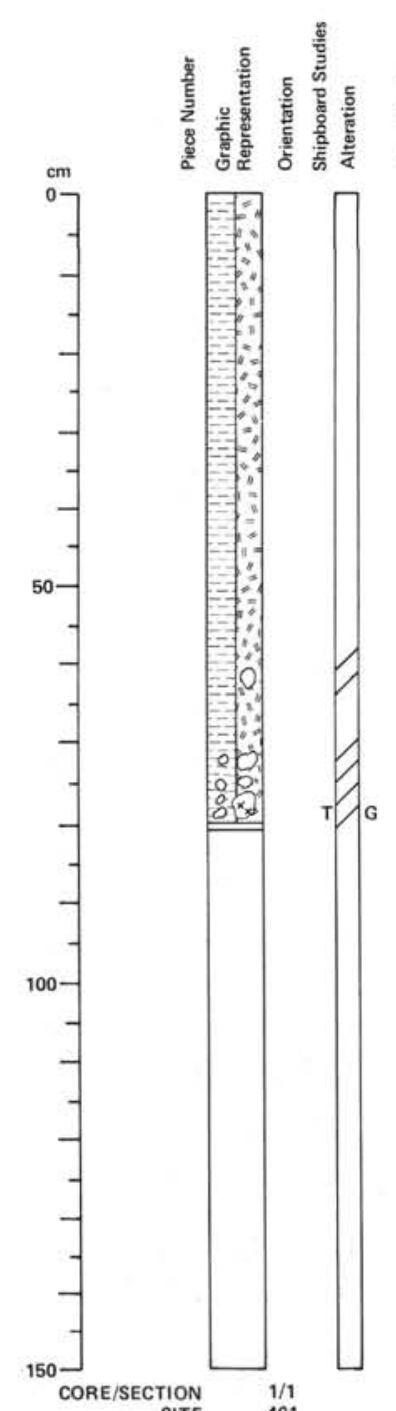

$\begin{array}{ll}\text { TION } & 1 / 1 \\ \text { SITE } & 461\end{array}$

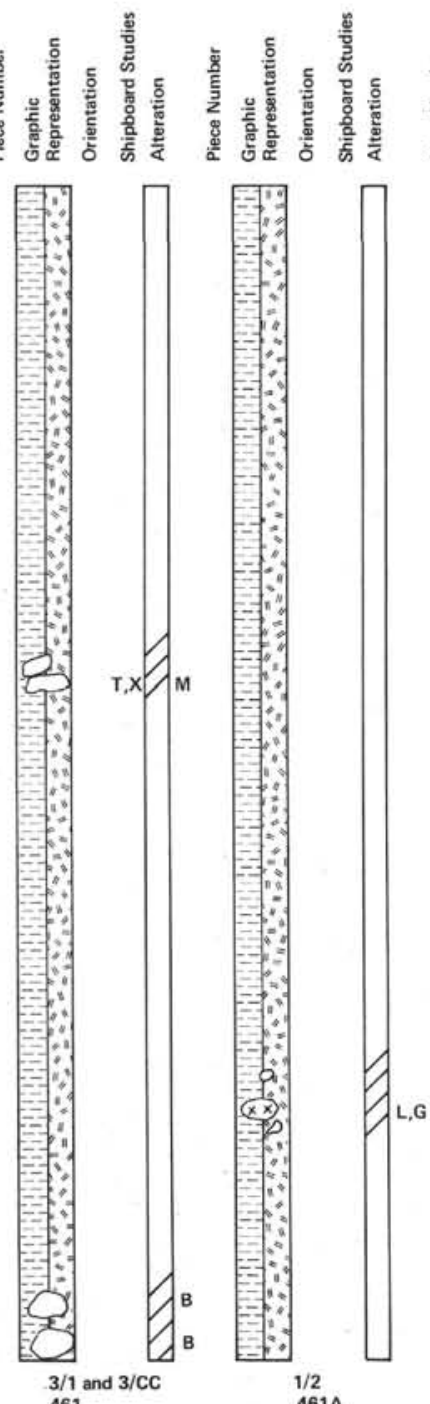

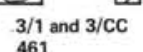

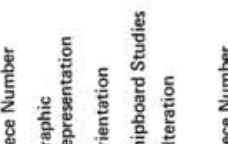
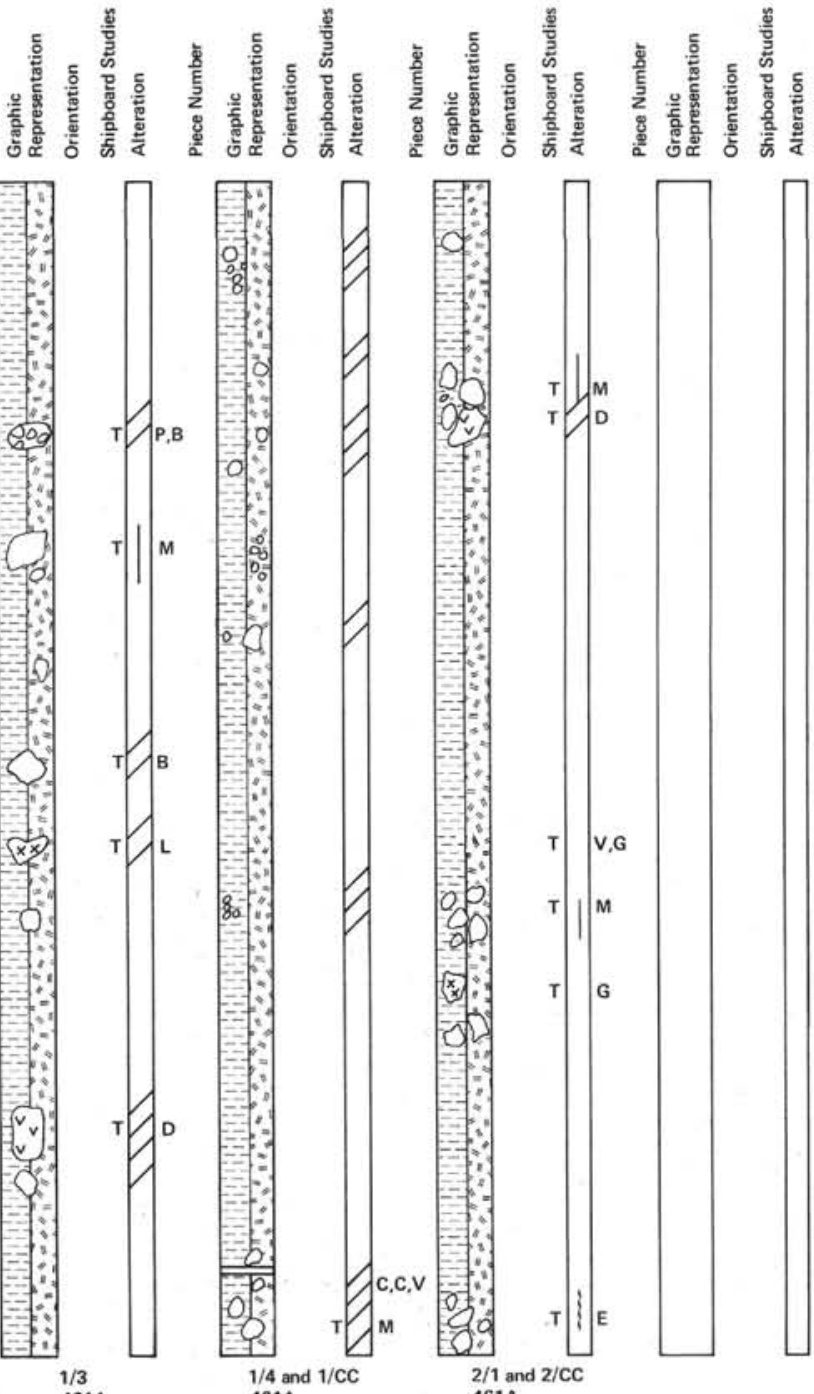

The sections shown here from two holes and five different cores at Sine 461 contain cobbles of igneous and metamorphic rocks They are mplified from the more accurste lithologies shown an the sediment sections, and are designatod where their lithology is known by letters $\begin{array}{llll}B & =\text { basalt } & D & =\text { diabse } \\ G & =\text { gabbro } & \text { VG } & =\text { volcanic quas }\end{array}$

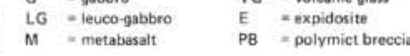

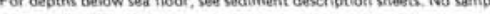

Petrographic Summar

Half of the rocks are metabasalts and metodiabases. The most altered
varieties contain (andesine?) together with quartz forms the granoblastic matrix of these rocks. The parrly recrystallized plagsoclases encloss the original

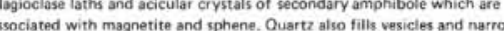
veins. True poikiloblasts of plag ioclase enclosing amphibole, magnetite a itrain tonstawever, even in this rock no real foliation of other kind a

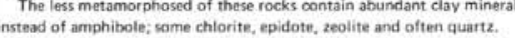
(a) and comproic cobbles are less abundant (25\%) The fond more variable in texture $\mathrm{cm}$ ) is a two-pyroxene gabbro with granular texture containing plagioclase

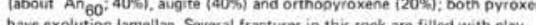
minerals, but otherwises socondary minerals are absent Other gabbroic clasts, presumably of the same original composition are more intensively aitered and usualiv contain secondary quartz and amphibole sccompanied cumulus minerals before alteration. In the highly altered spo wis 14.,78.80 cm, poikilobiasts of amphibole enclose the plagioclase and

One of the gabbro piects contains brecciasted materilal adhered to one
side of the fragment and some others have tectonized surferes indicating a possible origin from brecciated source materials, This is evidenced by

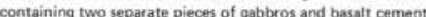
matrix with angular, sometimes very fine-grained gabbroic clasts. The other studied rock types are:

2) Astered (clay only) sparsely phyric, vesicular augiteplagioclase

basalt ; and ters pieces of almost completety 


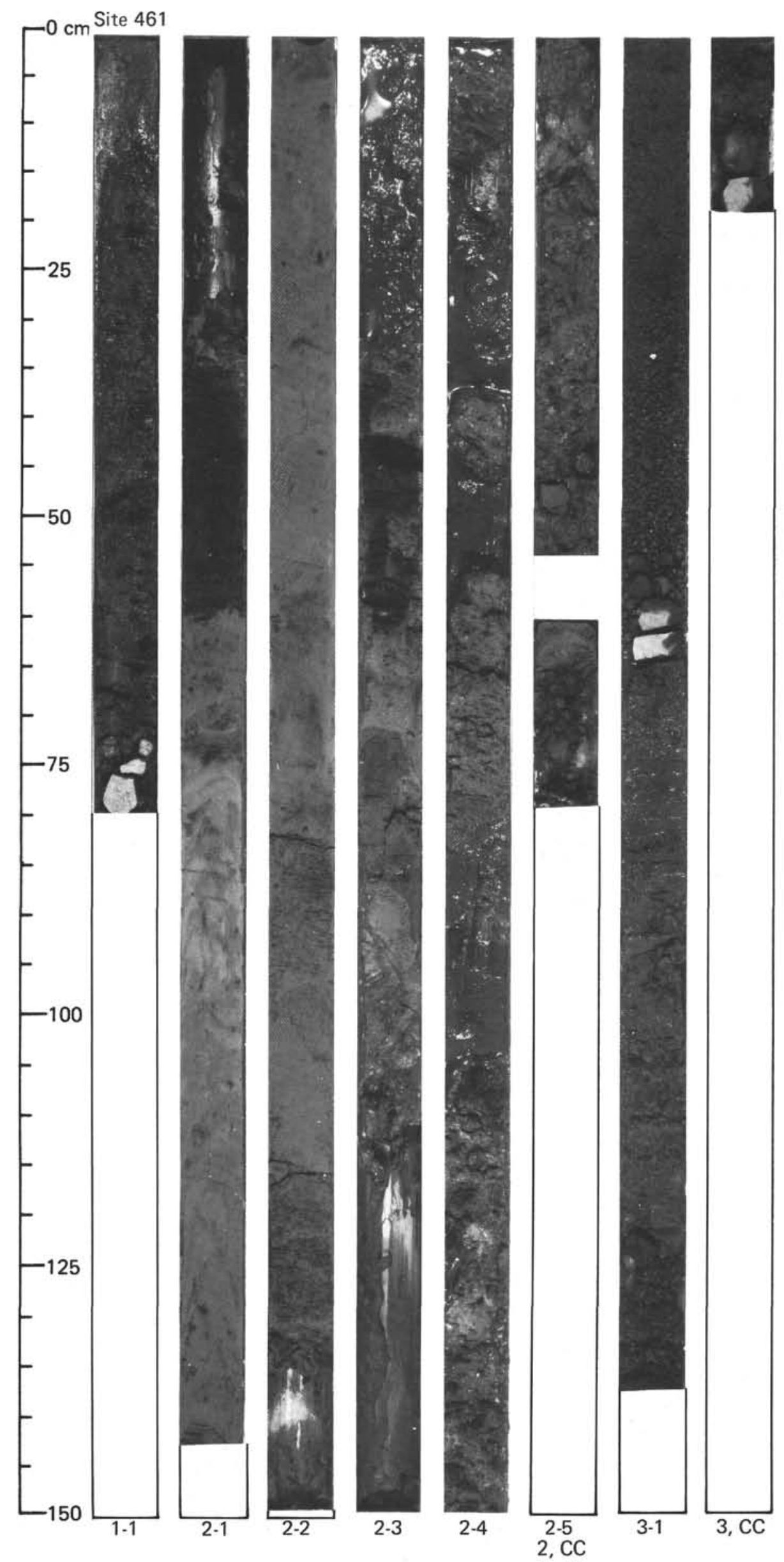




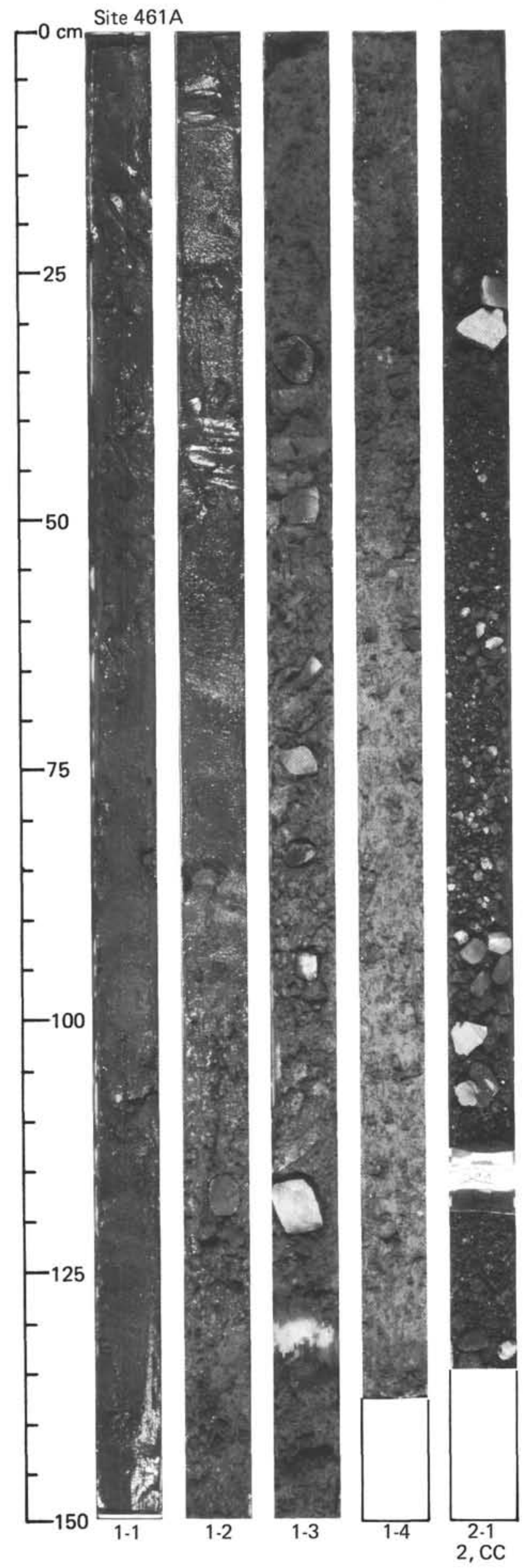

